\title{
Significance of the Epithelial Crypts at the Bovine Utero-Tubal Junction in the Pre-Ovulatory Phase of Sperm Regulation
}

\author{
By R.H.F. Hunter* \\ *University of Edinburgh, Edinburgh, Scotland, UK, and Department of Clinical Studies - Reproduction, The \\ Royal Veterinary and Agricultural University, Frederiksberg, Denmark.
}

\begin{abstract}
Hunter, R.H.F.: Significance of the epithelial crypts at the bovine utero-tubal junction in the pre-ovulatory phase of sperm regulation. Acta vet. scand. 1995, 36, 413421. - Because polyspermic fertilisation is a pathological condition in mammals, arising from an excess of spermatozoa at the site of initial sperm-egg contact and leading to early death of the embryo, consideration has been given to the manner whereby the utero-tubal junction may contribute to a reduction in the numbers of spermatozoa entering the Fallopian tubes. This seems especially important in cattle since the utero-tubal junction does not exhibit swollen polypoid processes that might act physically to reduce the number of spermatozoa entering the isthmus from the uterus.

In tissues prepared from animals close to the time of ovulation, large numbers of simple glands were visible in the uterine surface and throughout the region of the utero-tubal junction and its ridges extending into the isthmus. The glands appeared as crypts, slits or craters. On the basis of a figure of 500 glands situated close to the utero-tubal junction and some 2-10 spermatozoa located within each gland, these conservative estimates suggest a temporary arrest of $1-5 \times 10^{3}$ spermatozoa, thereby contributing to the steeply diminishing sperm gradient before the site of fertilisation. There would thus appear to be a vital physical rôle for the simple glands and clefts that predominate in this region, functioning importantly in the pre-ovulatory interval to pave the way for normal monospermic fertilisation. More subtle forms of sperm regulation by glycoprotein molecules are also considered.
\end{abstract}

sperm transport; sperm gradient; fertilisation; polyspermy; embryonic death; Fallopian tube; uterine glands; glycoproteins.

\section{Introduction}

Successful completion of the process of fertilisation is a vital part of fertility. Normal fertilisation depends upon the establishment of a 'sperm gradient' in the female genital tract. In the pre-ovulatory situation, the number of spermatozoa in the lumen of the tract diminishes steeply between the site of ejaculation in the va-

\footnotetext{
* On leave until 1. July 1995.
}

gina (approximately $10^{10}$ spermatozoa) and the anticipated site of initial sperm-egg contact in the Fallopian tube at the isthmo-ampullary junction $\left(<10^{2}\right.$ spermatozoa). In fact, sperm: egg ratios may be close to unity at the time of activation of the secondary oocyte under conditions of spontaneous mating (Hunter 1993). In the absence of an appropriate and sufficient reduction in sperm numbers before the mid portion of the Fallopian tubes, the newly-activated egg would be confronted by an excess of sper- 
matozoa, leading to the condition of polyspermic fertilisation in a high proportion of such eggs (Hancock 1962, Thibault et al. 1973). Polyspermy - that is penetration of the egg vitellus by more than 1 spermatozoon - is pathological in mammals (unlike the situation in fish and birds), and invariably results in preimplantation loss of the abnormal embryo (Beatty 1957, Piko 1961, Austin 1963).

Although the cervix is the principal anatomical barrier to transport of spermatozoa after mating in cattle, acting to reduce the sperm population presented to its mucus-filled canal by a factor of $10^{2}-10^{3}$ or more, a further steep reduction in numbers is achieved between the uterus and isthmus of the Fallopian tubes. Indeed, this further reduction between uterus and tubes is an essential preliminary to normal fertility after intra-uterine insemination with a Cassou straw, even though the sperm population so introduced has been carefully adjusted by dilution of the cell suspension (Hunter 1980). A critical question therefore arises as to how the reduction in sperm numbers is achieved at the uterotubal junction. Studies using the introduction of radio-opaque oil into the uterus of mature heifers suggested that such fluid passes progressively into and along the Fallopian tubes of oestrous animals (Rowson 1955), so that a comparable passage of fluid, if not its cellular content, might be anticipated with a suspension of spermatozoa. In cattle, the utero-tubal junction is not a swollen, valve-like structure as, for example, in pigs. In the latter species, the oedematous polypoid processes protruding from the tubal isthmus prevent fluid entry from the uterine site of semen accumulation into the Fallopian tubes (Hunter 1973, 1975, 1980). On the contrary, the bovine utero-tubal junction is a relatively simple structure, representing primarily a reduction in size of the lumen from the uterus to the isthmus (Hafez \& Black 1969, Thibault 1973, Hafez 1974).
Examination of the zona pellucida of recentlyfertilised cow eggs revealed low numbers of accessory spermatozoa associated with or embedded in that protective coat (Laing 1945, 1957, Hunter \& Wilmut 1982, 1984). So, once again, the question arises as to the nature of the quantitative control imposed on passage of bull spermatozoa at the utero-tubal junction during oestrus and up until the time of ovulation. Over and above a major influence of the size of the duct lumen, there would appear to be a critical rôle for the simple glands and clefts that predominate in this region of the female tract. The principal message of this paper is to indicate that these glands and clefts would function importantly in the pre-ovulatory interval to regulate the numbers of spermatozoa passing into the Fallopian tubes. Coupled with the ensuing sperm-epithelial interactions in the isthmus (Hunter 1994, 1995), the glands would impose a diminishing sperm gradient sufficient to ensure normal monospermic fertilisation. Although the role of these glands is examined largely in a physical context, a more subtle retardation of sperm progression may be associated with the presence of specific cell adhesion molecules (Hunter 1994). The present study considers quantitative regulation of sperm numbers by the glands.

\section{Materials and methods}

Animals

Tissues were examined from a total of 13 Friesian, Friesian crosses and Canadian Holstein animals. They were sexually mature, aged approximately $15-18$ months, and weighed 330 $465 \mathrm{~kg}$. They were bedded on straw, fed a diet of concentrates and good quality hay, and given continuous access to fresh water. They had not been subjected to any previous mating or experimental work nor to hormonal treatments for the regulation of oestrous cycles or induction of ovulation. Two bulls were kept in adjacent pens, 
separated from each other and the females by tubular steel bars.

\section{Experimental procedures}

Unrestrained animals were checked for the onset of oestrus at least 4 times per day with an experienced teaser bull. Mating was performed during the first 4-6 $\mathrm{h}$ of standing oestrus using a bull of proven fertility. Only if the mating was considered misaligned and intromission in doubt was a second mating performed ( 3 instances). Animals were then left undisturbed for at least $12 \mathrm{~h}$ before transport to a local abattoir. They were slaughtered on the first or second day after mating, shortly before or up to 29 $\mathrm{h}$ after ovulation. The procedures for preparing, fixing and examining tissues from the region of the utero-tubal junction by scanning electron microscopy were described in detail by Hunter et al. (1991). Counting procedures for the glands and clefts were made directly on the scanning electron micrographs whereas sperm numbers were assessed principally from sectioned tissue. The histological procedures for light microscopy followed those of Thibault et al. (1973).

\section{Results}

\section{Morphology of the utero-tubal junction}

The overall morphology of the utero-tubal junction and caudal-most portion of the isthmus is illustrated in Plate 1. Whilst the general form was comparable in all specimens, the degree of undulation of the surface contours was related to the time of ovulation. Pre-ovulatory preparations were more distended due to an oedematous condition of the mucosa, a situation that waned soon after ovulation, thereby acting to increase the patency of the utero-tubal junction and isthmus.

A significant narrowing of the tract was detectable at the utero-tubal junction, progressing from the tip of the uterine horn with its mildly undulating surface into the prominent folds, ridges, furrows and grooves of the isthmus (Figs 1, 2 \& 3). Viewed from the uterine aspect, a substantial obstacle to the ascent of spermatozoa was provided by the arrangement of noncontinuous folds into cul-de-sacs or deep grooves (diverticulae) orientated obliquely in the caudal isthmus. This impediment was accentuated in the oedematous pre-ovulatory situation.

\section{Presence of spermatozoa in glands}

At higher magnification (Fig. 4), the further subdivision of ridges and folds by prominent slits, clefts or diverticulae arranged in a transverse or oblique manner was conspicuous. Large numbers of simple glands were visible in the uterine surface and throughout the region of the utero-tubal junction and its ridges extending into the isthmus. The glands appeared as crypts, slits or craters, sometimes associated with tufts of cilia. In these fixed preparations, significant amounts of secretion were not observed in or emerging from the glands during the interval studied. The presence and disposition of spermatozoa within such glands is illustrated in Figs 5-8. No consistent orientation of spermatozoa towards, or intimate arrangement with, the epithelium could be discerned in these light microscope preparations, although there was a suggestion in one of the figures that the rostral portion of the sperm head was specifically apposed to the epithelial surface (Fig. 5). However, as revealed by scanning electron microscopy, intimate contact with microvilli was characteristic of spermatozoa in the isthmus in the pre-ovulatory situation.

\section{Estimated numbers of spermatozoa}

Simplified and conservative estimates can be made of the reduction in sperm numbers that would be imposed by the glandular nature of the utero-tubal junction, on both its uterine side 

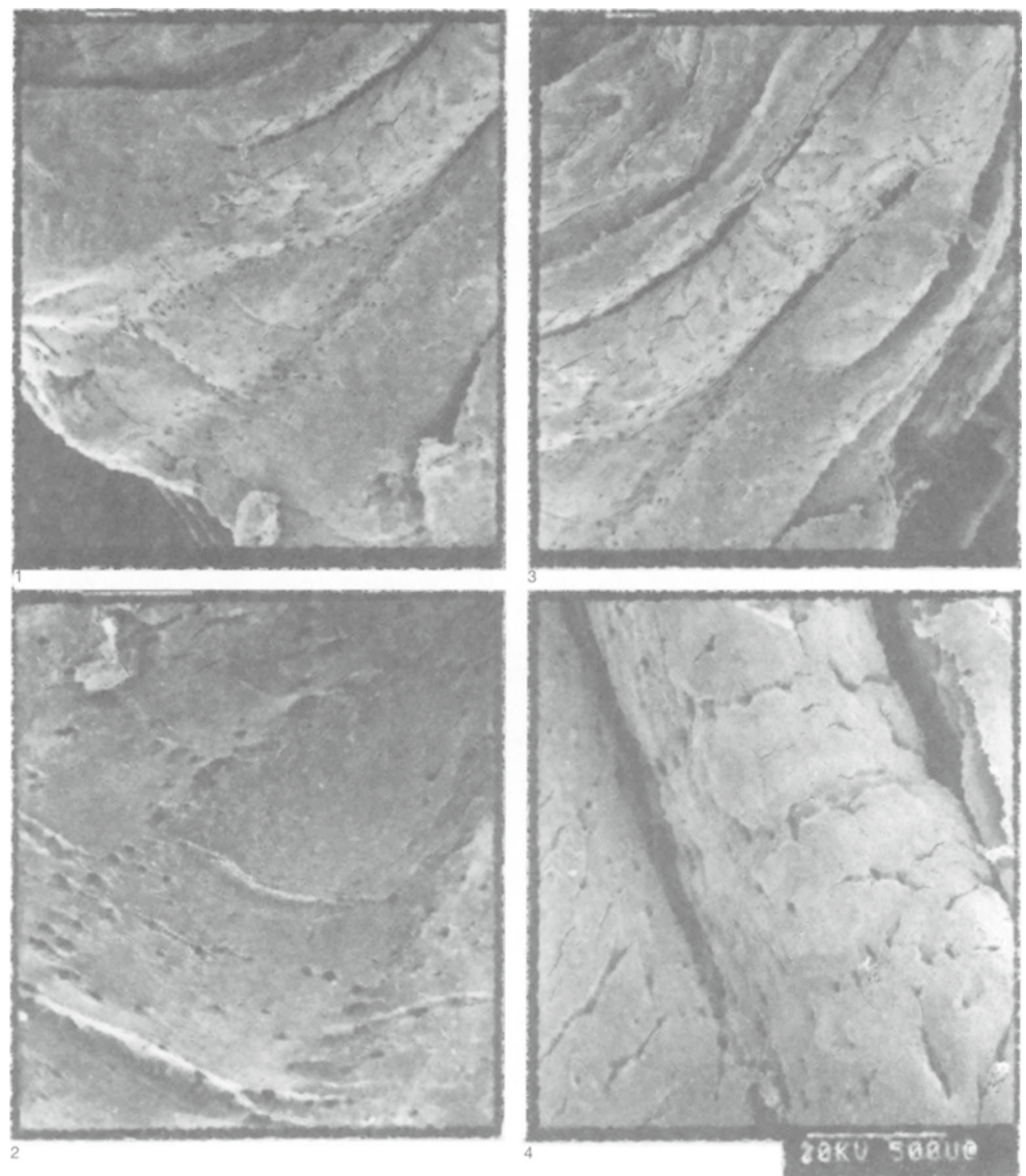

Figures 1-4. Scanning electron photomicrographs of the region of the utero-tubal junction and its close vicinity prepared from mated cows shortly after the time of ovulation.

Fig. 1 and 2 focus on the utero-tubal junction itself; Fig. 3 examines the rostrally-adjacent portion to show some of the prominent longitudinal ridges that extend into the caudal isthmus of the Fallopian tube; and Fig. 4 shows a portion of the isthmus with a ridge revealed at increased magnification. Note the distribution of prominent, simple glands, slits or diverticulae, and folds in all the preparations, and also the varied orientation of the slits and folds. Magnification is indicated by the white bar line and scale given in Fig. 4. 

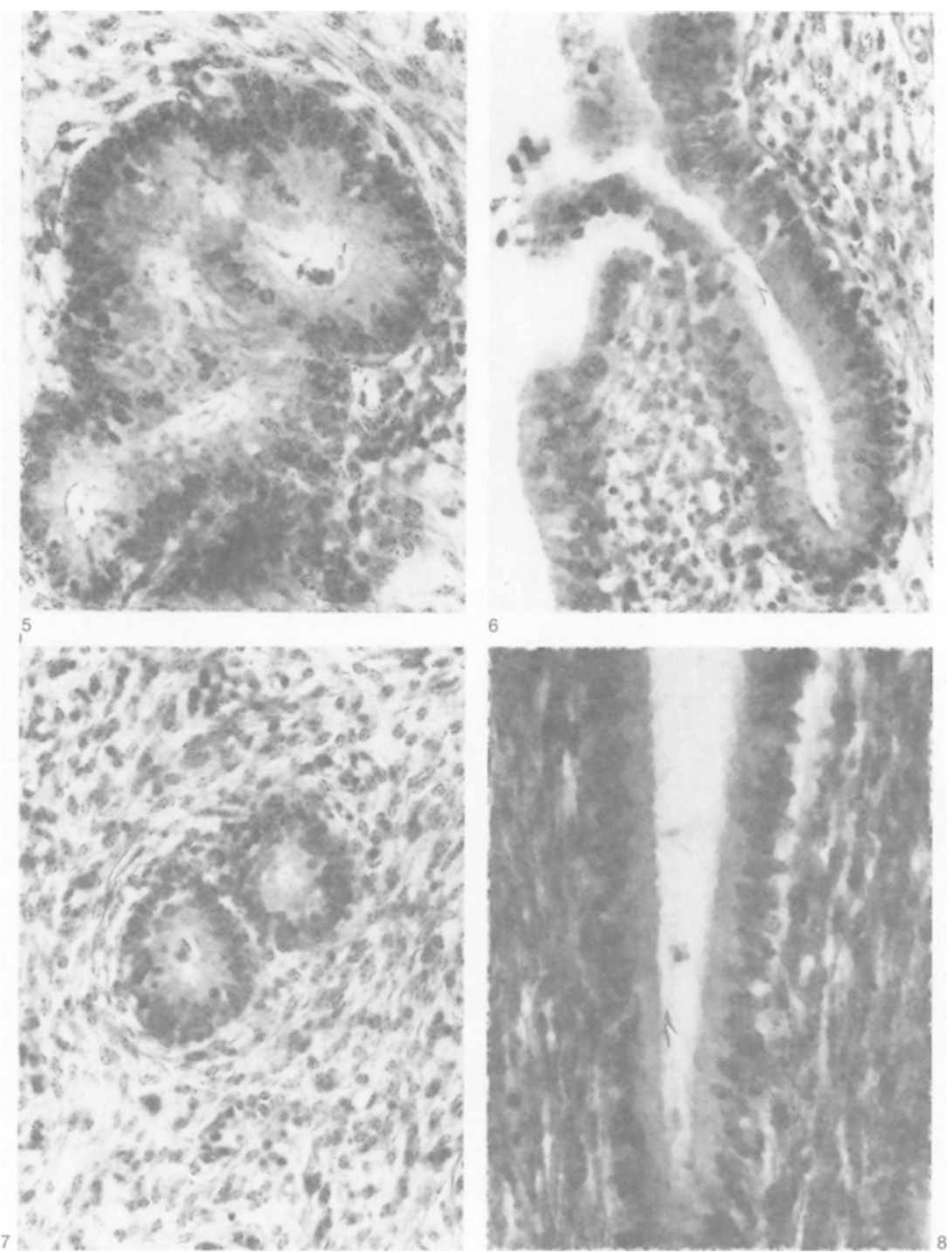

Figures 5-8. Fixed and stained preparations of tissues from the regions of the utero-tubal junction and proximal uterine cornua of 4 mated cows. Fig. 5. Section through uterine glands $8 \mathrm{~h}$ after mating to show spermatozoa entering and established within a gland. Orientation of the rostral portion of the sperm head towards the epithelium is evident in many instances. Fig. 6. Section through a fold or slit on the uterine side of the utero-tubal junction some $18 \mathrm{~h}$ after mating showing a small number of spermatozoa distributed along the length of the gland. Fig. 7. Section through a region of the uterine cornua close to the utero-tubal junction prepared $48 \mathrm{~h}$ after mating showing a sperm cell being incorporated by a polymorphonuclear leucocyte within the lumen of the gland. Fig. 8. A further preparation from an animal $48 \mathrm{~h}$ after mating revealing the presence of spermatozoa in a gland (fold) at the utero-tubal junction. No specific orientation of the sperm head with regard to the epithelium was revealed, nor can phagocytosis of spermatozoa be distinguished in this preparation. 
and that of the isthmus in its most caudal portion. Based on a calculation of approximately 500 glands in this region, and of some 2-10 spermatozoa in each gland during the pre-ovulatory phase, then a temporary arrest of 1,000 5,000 spermatozoa could be anticipated. In fact, careful examination of Plates 1 and 2 would suggest that these calculations are an underestimate, and therefore that the sperm gradient imposed by the epithelial glands and clefts is far more important. Even so, a potential reduction by a factor of $10^{3}$ spermatozoa ascending the lumen of the tract across the uterotubal junction would contribute in a major way to controlling the number of spermatozoa able to approach the isthmo-ampullary junction in the pre-ovulatory interval.

\section{Discussion}

The principal point arising from these observations is that sperm entry into, and pre-ovulatory arrest within, epithelial glands close to the utero-tubal junction would act to promote the chances of normal fertilisation of the cow egg. By imposing a sperm gradient between the uterine lumen and that of the Fallopian tube, the glands would contribute powerfully to avoidance of the pathological condition of polyspermic fertilisation of the newly-shed egg. This would be especially so if the reduction in sperm numbers imposed in the pre-ovulatory interval were, as calculated, of the order of $\geqslant 10^{3}$ across the region of the junction. This glandular means of achieving a sperm gradient may be essential in the absence of valve-like structures at the utero-tubal junction, as in the rabbit (Hafez \& Black 1969), or swollen polypoid processes, as in the pig (Hunter 1973, Fléchon \& Hunter 1981). In the latter species, semen enters the uterus almost directly during mating, with a sperm concentration of $1-2 \times 10^{8}$ cells per ml bathing the utero-tubal junction by the completion of mating, so a more formidable and effective means of reducing the numbers of spermatozoa and preventing seminal plasma entering the Fallopian tubes is required at the utero-tubal junction. In the absence of comparable arrays of glandular structures in the pig, the highly distended polypoid processes that represent extremities of the longitudinal folds of the isthmus furnish such a means (Hunter 1973, 1980).

The overall morphology of the bovine utero-tubal junction appears relatively simple (Hafez \& Black 1969, Thibault 1973, Thibault et al. 1973, Hafez 1974), and this would offer one explanation for the seemingly-free access of radio-opaque oil into the isthmus recorded by Rowson (1955) after intra-uterine insemination. However, the site of ejaculation in cattle is the anterior vagina, close to the external os of the cervix, and only a fraction of the motile ejaculated spermatozoa would succeed in entering the cervical canal. An even smaller proportion of spermatozoa would subsequently leave this mucus-filled channel to enter the body of the uterus. The reduction in sperm numbers across the cervix may be of the order of $10^{2}$ ( Hafez 1974, Hunter 1980). A further tenfold reduction or more is found along the length of the uterine horn (Austin 1965), so that an initial figure of $10^{10}$ spermatozoa in the anterior vagina would be reduced towards $10^{7}$ before the region of the utero-tubal junction, probably closer to $10^{6}$ spermatozoa in each of the 2 uterine horns. On the basis of calculations made from the present observations, entry of spermatozoa into glands in the region of the utero-tubal junction could effect a further reduction of $\geqslant 10^{3}$ cells, quite apart from any associated influence of a reduction in size of the lumen of the tract. Thus, the number of spermatozoa ascending the isthmus towards the site of fertilisation would be about $10^{3}$ in total, and probably very significantly less at any given time after mating. In fact, the observations of Thibault (1973), Thi- 
bault et al. (1973), Larsson \& Larsson (1986) and Hyttel et al. (1991) all suggest remarkably small numbers of spermatozoa ascending the isthmus at any particular time.

As to the rate of progression of functional spermatozoa to the utero-tubal junction and beyond in cattle, a surgical approach to this question enabled Hunter \& Wilmut $(1982,1984)$ to record a period of 10-12 $\mathrm{h}$ after a single mating early in oestrus as a minimum interval for sufficient spermatozoa to enter the isthmus subsequently to effect fertilisation. Such studies inferred both a slow, progressive transport and migration of competent spermatozoa to the utero-tubal junction early in oestrus, as suggested by Thibault (1973), and an effective means of regulating sperm passage through this junction and within the isthmus. Indeed, as judged from the low numbers of accessory spermatozoa on fertilised eggs, control of sperm numbers entering the Fallopian tubes from the uterus was highly effective. Repeated matings throughout the period of oestrus might act to alter this situation, although this could not be demonstrated in sheep (Hunter \& Nichol 1986), perhaps due to a downgrading of oxytocin receptors in the Fallopian tubes (Hunter 1991, 1995). However, any enhancement of sperm numbers entering the uterus would be counteracted by the very substantial numbers of polymorphonuclear leucocytes infiltrated into the uterine lumen as a specific consequence of the first mating. Such leucocytes would therefore regulate the number of spermatozoa potentially available to the Fallopian tubes.

Not to be overlooked is the fact that this paper has focused upon purely a physical influence of glands close to the utero-tubal junction in regulation of the process of sperm transport. In the physiological situation, more subtle forms of sperm hindrance or arrest would also need to be considered. Kann \& Fouquet (1977) produced an hypothesis of sperm filtering and selec- tion at the utero-tubal junction without, however, explaining or even suggesting the means of achieving such influences. As far as sperm regulation is concerned, other means could involve the influence of viscous proteinaceous secretions (see Overstreet 1983, Hunter et al. 1991), interactions with epithelial cilia (Pollard et al. 1991) or microvilli (Hunter et al. 1991), and/or the specific influence of cell adhesion molecules such as cadherins acting in and close to the glands to impede sperm progression on a temporary basis (Hunter 1994). The studies of Garcia-Villar et al. (1982) in sheep on the direction of contractile activity might also lead one to consider a possible role of myometrial movements propagated away from the uterotubal junction towards the cervix in the preovulatory situation. However, it would be difficult to reconcile the fact of sperm progression in the female tract in an ad-ovarian sense with the concept of powerful abovarian waves of contraction, unless there was a mixture of myometrial waves in both directions (see Rousseau \& Ménézo 1993).

As a final thought, it would be of considerable value to repeat the experiment of Rowson (1955) in a carefully-timed study to establish whether the bovine utero-tubal junction really is patent to the gross passage of fluid during oestrus and before ovulation has occurred. Several considerations strongly suggest that uterine fluids would not pass freely into the isthmus before or very soon after ovulation, not least because of the suspension of polymorphonuclear leucocytes that they could transmit: such phagocytes are seldom observed in the lumen of healthy Fallopian tubes in cattle (Hunter et al. 1991). It is possible that the interval between slaughter and excision of the reproductive tract in Rowson's (1955) study, together with the dramatic contractions of the myometrium and myosalpinx stimulated by the actual procedure of slaughter, contributed to an artefa- 
ctual displacement of the radio-opaque fluid through and beyond the region of the uterotubal junction, at least in some specimens. The highly oedematous condition of this structure in the pre-ovulatory phase would have been expected to obscure the lumen of the isthmus and, together with the presence of viscous secretions, would thereby have inhibited any bulk transport of fluid promoted by uterine contractions. Displacement of uterine fluid towards the cervix (Rousseau \& Ménézo 1993) would clearly also have acted to reduce a physiological passage into the Fallopian tubes.

In conclusion, there would appear to be a vital physical role for the simple glands and clefts that are a feature of the bovine utero-tubal junction. Their contribution to the steeply-diminishing sperm gradient paves the way for normal monospermic fertilisation.

\section{Acknowledgements}

I am especially grateful to Professor C. Thibault and Dr. J.E. Fléchon of the Institut National de la Recherche Agronomique, Jouy-en-Josas, France, for assistance with the photographic material, and to Frances Anderson in Edinburgh for preparation of the typescript. The study was supported in part by a grant from the Agricultural Research Council (U.K.) which is also gratefully acknowledged.

\section{References}

Austin CR: Fertilisation and transport of the ovum. In: Hartman CG (ed.). Mechanisms Concerned with Conception. Pergamon Press, Oxford, 1963, pp. 285-320.

Austin CR: Fertilisation. Prentice-Hall, New Jersey. 1965 , pp. 53-55.

Beatty, RA: Parthenogenesis and Polyploidy in Mammalian Development. Cambridge University Press, Cambridge, 1957.

Fléchon JE, Hunter RHF: Distribution of spermatozoa in the utero-tubal junction and isthmus of pigs, and their relationship with the luminal epithelium after mating: a scanning electron microscope study. Tissue Cell, 1981, 13, 127-139.

Garcia-Villar R, Toutain PL, More J, Ruckebusch Y: Spontaneous motility of the cervix in cyclic and ovariectomised ewes and changes induced by exogenous hormones. J. Reprod. Fert. 1982, 66, 317-326.

Hafez ESE: Functional anatomy of female reproduction. In: Hafez ESE (ed.): Reproduction in Farm Animals. Lea \& Febiger Philadelphia 1974, pp . 24-53.

Hafez ESE, Black DL: The mammalian utero-tubal junction. In: Hafez ESE, Blandau RJ (eds.): The Mammalian Oviduct 1969, pp. 85-126. Chicago: University of Chicago Press.

Hancock JL: Fertilisation in farm animals. Anim. Breed. Abstr. 1962, 30, 285-310.

Hunter RHF: Transport, migration and survival of spermatozoa in the female genital tract: species with intra-uterine deposition of semen. In: Hafez, ESE \& Thibault C. (eds.): Sperm Transport, Survival and Fertilising Ability. INSERM Paris, 1973, pp. 309-342.

Hunter RHF: Transport, migration and survival of spermatozoa in the female genital tract: species with intra-uterine deposition of semen. In: Hafez, ESE \& Thibault, C. (eds). The Biology of Spermatozoa. Karger Basel, 1975, pp. 145-155.

Hunter RHF: Physiology and Technology of Reproduction in Female Domestic Animals. Academic Press London \& New York, 1980.

Hunter RHF: Behaviour of spermatozoa in the oviduct of farm animals. Arch. Biol. Med. Exp., 1991, 24, 349-359.

Hunter RHF: Sperm:egg ratios and putative molecular signals to modulate gamete interactions in polytocous mammals. Molec. Reprod. Devopt 1993, 35, 324-327.

Hunter RHF: Vagues de spermatozoides de Hammond et dernières hypothèses sur le transport des spermatozoides pour la rencontre avec l'ovule. Méd. Vét. Québec, 1994, 24, 43-47.

Hunter, RHF: Ovarian endocrine control of sperm progression in the Fallopian tubes. Oxford Rev. Reprod. Biol. 1995, 17, 85-125.

Hunter RHF, Nichol R: Post-ovulatory progression of viable spermatozoa in the sheep oviduct, and the influence of multiple mating on their pre-ovulatory distribution. Brit. Vet. J., 1986, 142, 52-58.

Hunter, RHF \& Wilmut, I: The rate of functional sperm transport into the oviducts of mated cows. Anim. Reprod. Sci., 1982, 5, 167-173.

Hunter, RHF, Wilmut I: Sperm transport in the cow: peri-ovulatory redistribution of viable cells within the oviduct. Reprod. Nutr. Dévelop., 1984, 24, 597-608. 
Hunter, RHF, Fléchon B, Fléchon JE: Distribution, morphology and epithelial interactions of bovine spermatozoa in the oviduct before and after ovulation: a scanning electron microscope study. Tissue and Cell, 1991, 23, 641-656.

Hyttel P, Callesen H, Greve T, Schmidt M: Oocyte maturation and sperm transport in superovulated cattle. Theriogenology, 1991, 35, 91-108.

Kann ML, Fouquet JP: Bull spermatozoa in the female tract after natural mating. A preliminary ultrastructural study of the utero-tubal junction. Annls. Biol. Anim. Biochim. Biophys., 1977, 17, 165-172.

Laing JA: Observations on the survival time of spermatozoa in the genital tract of the cow and its relation to fertility. J. agric. Sci., 1945, 35, 72 83.

Laing JA: Female fertility. In: Hammond J. (ed.) Physiology of Farm Animals. Butterworth, London, 1957, 3, 760-792.

Larsson B, Larsson $K$ : Sperm localisation in the oviducts of artificially inseminated dairy cattle. Acta vet. scand., 1986, 27, 303-312.

Overstreet $J W$ : Transport of gametes in the reproductive tract of the female mammal. In: Hartmann, JF (ed.): Academic Press, New York, 1983, pp. 499-543.

Piko L: La polyspermie chez les animaux. Annls. Biol. Anim. Biochim. Biophys., 1961, 1, 323383.

Pollard JW, Plante C, King WA, Hansen PJ, Betteridge KJ, Suarez SS: Fertilising capacity of bovine sperm may be maintained by binding to oviductal epithelial cells. Biol. Reprod. 1991, 44, 102-107.

Rousseau JP, Ménézo Y: Role of the female genital tract in the transport and survival of gametes and the fertilised egg. In: Thibault C, Levasseur MC, Hunter RHF (eds.): Reproduction in Mammals and Man. Ellipses, Paris, 1993, pp. 369-386.

Rowson LEA The movement of radio-opaque material in the bovine uterine tract. Brit. Vet. J., 1955, $111,334-342$.
Thibault C: Sperm transport and storage in vertebrates. J. Reprod. Fert. Suppl., 1973, 18, 39-53.

Thibault C, Gerard M, Heyman Y: Transport et survie des spermatozoides chez la vache. In: Hafez, ESE \& Thibault C. (eds.): INSERM Paris, 1973, Sperm Transport, Survival and Fertilising Ability pp. 343-356.

\section{Sammendrag \\ Regulering af den pra-ovulatoriske spermiekoncent- ration i epithelkrypterne $i$ uterus og ovidukt}

Da polyspermi er en patologisk tilstand hos pattedyr, der opstår som følge af et for højt antal spermatozoa i det område af tuba uterina, hvor spermatozo-oocyt kontakten etableres, og som medfører tidlig embryonal død, gives der i nærværende artikel nogle betragtninger over mekanismerne, hvormed den uterotubale forbindelse bidrager til at regulere antallet af sædceller. Mekanismerne synes specielt betydningsfulde hos kvæg, idet den utero-tubale overgang ikke har svulne polyploide processer, som formentlig rent fysisk reducerer antallet af spermatozoa, som passerer ind $\mathrm{i}$ isthmus lumen fra uterus.

I vævsprøver udtaget fra dyr tæt på ovulations tidspunktet var et større antal simple kirtler synlige på den uterine overflade og $i$ hele den utero-tubale overgang, og epithelfolder herfra var ligeledes synlige i isthmus delen. Kirtlerne præsenterede sig som krypter, spalter eller kratre. Baseret på et antal af cirka 500 kirtler placeret tæt på den utero-tubale overgang og omkring 2-10 spermatozoa i hver kirtel, peger et groft skøn på, at kun cirka 1-5 x $10^{3}$ spermatozoa kortvarigt opholder sig i denne region, hvorved antallet af sædceller, som efterfølgende når stedet, hvor befrugtningen finder sted, reduceres betydeligt. Det synes således, at de simple kirtler og spalter, som dominerer i denne region, har en afgørende funktionel rolle i den præovulatoriske periode, så der banes vej for fertilisation med blot en enkelt spermatozo. Mere diskrete former for regulation af spermatozoa ved hjælp af glycoproteiner omtales ligeledes.

(Received May 1, 1995; accepted May 22, 1995).

Reprints may be requested from: R. H. F. Hunter, Institut für Tierzucht und Haustiergenetik, Georg-AugustUniversität Göttingen, Albrecht-Thaer-Weg 3, D-37075 Göttingen, Germany. 
